\title{
ODNOS PREBIVALCEV MESTNE OBČINE KOPER DO LUKE KOPER
}

\author{
Mateja Pirc, Klemen Strmšnik, Jurij Dobnik* \\ Raziskovalni projekt študentov 4 . letnika geografije študijske usmeritve \\ Varstvo geografskega okolja
}

Pregledni znanstveni članek

COBISS 1.02

\section{Izvleček}

Med delom prebivalcev Mestne občine Koper se je oblikoval izrazito negativen odnos do Luke Koper, upravitelja edinega slovenskega pristanišča, ki naj bi svoje dejavnosti razširilo na tretji pomol. S pomočjo anketiranja smo prikazali, kakšen je dejanski odnos do Luke Koper na ravni celotne občine, zakaj je prišlo do negativnega odnosa med delom prebivalstva, katere skupine nasprotujejo širitvi ter kakšne okoljske vplive pristanišča zaznavajo na različnih območjih v občini.

Ključne besede: Luka Koper, koprsko pristanišče, anketiranje, tretji pomol, vplivi na okolje.

\section{THE ALTITUDE OF THE INHABITANTS OF THE KOPER MUNICIPALITY TOWARDS THE PORT OF KOPER}

\begin{abstract}
A distinctly negative attitude towards Luka Koper lately developed among a certain part of the Koper residents. This is due to the fact that Luka Koper, the owner of the only Slovenian port, intends to expand its port and logistic services and start intensive construction at Pier III. With the help of our survey we have shown what the general attitude towards Luka Koper is like on the level of the whole community in Koper, as well as explained the reasons for this growing dissatisfaction among the people. We have also defined the resident groups that oppose the expansion of the port and presented the effects of the port which residents detect in different areas of their community.
\end{abstract}

Key words: Luka Koper, port of Koper, inquiry, the third pier, impacts on the environment.

\footnotetext{
* Študentje 4. letnika v študijskem letu 2004/2005, Oddelek za geografijo, Filozofska fakulteta Univerze v Ljubljani, Aškerčeva 2, 1000 Ljubljana
} 


\section{UVOD}

Mestna občina Koper je v začetku leta 2005 objavila razpis za sofinanciranje okoljskih in naravovarstvenih ozaveščevalnih projektov v Mestni občini Koper za leto 2005. Študentje s študijsko usmeritvijo Varstvo geografskega okolja smo se nanj odzvali z raziskovalnim projektom Odnos prebivalcev Mestne občine Koper do Luke Koper. Ukvarjali smo se z aktualno problematiko načrtovane širitve edinega slovenskega pristanišča. V želji ostati konkurenčna drugim severno jadranskim pristaniščem, želi Luka Koper svoje pristaniške dejavnosti širiti na tretji pomol. Del prebivalstva občine Koper širitvi odločno nasprotuje.

\section{NAMENI, CILJI, METODOLOGIJA}

Glavni namen projekta je bil prikazati, kako različne skupine prebivalcev Mestne občine Koper sprejemajo načrtovano širitev pristanišča. Ugotoviti smo želeli tudi, če se odnos do širitve v občini prostorsko diferencira.

Cilji raziskovalnega projekta:

- ugotoviti, kako občani Mestne občine Koper zaznavajo okolje, kjer živijo (kot onesnaženo ali neonesnaženo), kateri okoljski problemi se jim zdijo najbolj pereči in kdo jih povzroča;

- $\quad$ v kolikšni meri pojmujejo Luko Koper kot onesnaževalca;

- $\quad$ ugotoviti, katere skupine prebivalcev poseg zavračajo, zakaj ga zavračajo ter kje so morebitni razlogi nezaupanja do Luke Koper;

- $\quad$ prikazati, kakšen je odnos občanov do pristanišča glede na lokacijo bivanja ter po strukturi prebivalstva.

Uporabljen socialnoekološki metodološki pristop nam je omogočil raziskovanje odzivnosti prebivalcev na onesnaženost $v$ njihovem okolju ter raziskovanje njihovega odnosa do načrtovane širitve pristanišča. Posameznikovo sprejemanje, razumevanje in zaznavanje degradiranega okolja namreč ne ustreza vedno njegovemu dejanskemu stanju. Prihajajoče informacije o okolju se po skupinah ljudi modificirajo različno (Plut, 2004). Različna mnenja o kakovosti bivalnega okolja, onesnaženosti ter vzrokih za njegovo degradiranost smo zajeli z obsežno anketo, prostorsko diferenciacijo pa smo prikazali kartografsko.

Projekt je obsegal tri delovne faze. V prvi, ki je temeljila na kabinetnem delu, smo zbrali objektivne podatke o Luki Koper in o njenih vplivih na okolje. Oblikovali smo objektivno oceno stanja okolja in ovrednotili dosedanje okoljske vplive pristanišča. Zanimali so nas predvsem rezultati meritev emisij in imisij snovi in hrupa v zrak. Ker smo imeli s pridobivanjem podatkov več problemov (dostopni so nam bili samo podatki o merilnih mestih), smo se v prvi delovni fazi oprli predvsem na študijo o kvaliteti življenjskega okolja v koprski občini (Špes in drugi, 1998). Kvaliteta življenjskega okolja v koprski občini) ter na študijo o ranljivosti okolja na območju občine Koper (Špes, 2001).

Jedro raziskave je predstavljalo terensko delo - anketiranje v Mestni občini Koper. Izvedli smo 831 anket. Dvodnevnega terenskega dela, ki je potekalo 14. in 15. aprila 2005, se je udeležilo 56 študentov. 
Poleg mnenj lokalnega prebivalstva nas je zanimalo tudi, kako na načrtovano širitev pristanišča gledajo oblikovalci javnega mnenja, predstavniki oblasti ter tisti, ki o gradnji odločajo. Mnenja smo želeli zajeti s kratkim intervjujem, vendar smo naleteli na slab odziv.

V sklepni fazi projekta je sledila obdelava anket, izdelava grafičnih in kartografskih prikazov, analiza in interpretacija ter vrednotenje rezultatov.

Junija 2005 smo v Kopru predstavnikom občine, Luke Koper ter zainteresirani javnosti predstavili zaključke raziskave.

\section{GEOGRAFSKI ORIS OBMOČJA PREUČEVANJA}

Mestna občina Koper leži v Koprskem primorju, na območju z najbolj izrazitimi sredozemskimi potezami v Sloveniji. V zavesti državljanov je Koprsko primorje prisotno predvsem kot obmorska turistična, industrijska in pomorska prometna regija.

Z geografskega vidika je regija fiziognomsko homogena, omejena na eni strani s strmim kraškim robom in na drugi strani z morjem (Rejec Brancelj, 1994). Znotraj Koprskega primorja ločujemo dva pokrajinska tipa: priobalno ravnico z nižjim priobalnim gričevjem do približno 200 m nadmorske višine ter klimatsko in prometno manj ugodno višje flišno gričevje in kraško obrobje (Cigale, 2000). Na ožjem obalnem območju so naravne razmere zelo ugodne, zato večina populacije ( $>80 \%$ ) naših obalnih občin živi znotraj $1,5 \mathrm{~km}$ obmorskega pasu. Ta je zelo privlačen za različne dejavnosti (promet, trgovina, turizem, kmetijstvo, bivanje) (Potočnik, 2001), med katerimi se posledično pojavljajo konflikti, hkrati pa so z njimi povezane številne okoljske obremenitve (Cigale, 2000).

Slovensko teritorialno morje je del Tržaškega zaliva, ki je razmeroma plitev (povprečna globina je $16,4 \mathrm{~m}$, prostornina $9,5 \mathrm{~km}^{3}$ ). Na njegovo ekološko stanje poleg majhne količine vode vplivajo predvsem sladkovodni pritoki, obsežni morski sedimenti in naraščajoče onesnaževanje (ob Tržaškem zalivu živi prek 400.000 prebivalcev). Prevladujoči morski tok v obratni smeri urinega kazalca prinaša $\mathrm{v}$ zaliv južne pretežno oligotrofske vode onesnažene reke Pad (Potočnik, 2001). Voda v Severnem Jadranu se teoretično obnovi v dveh letih, kar je trikrat hitreje, kot je povprečje za celotno Jadransko morje. Obalno morje je že po naravi podvrženo evtrofikaciji, saj zaradi flišnega zaledja reke ob izlivu odlagajo velike količine flišnih preperelin in s tem hranljive snovi (Špes, 2000). Okoljski pritiski na proučevano območje so zaradi ugodne strateške lege ob Severnem Jadranu veliki in pričakovati je, da se bodo še stopnjevali.

Koprsko pristanišče je zaradi specifične geografske lege neposredno ob morski obali eden ključnih virov okoljskih pritiskov na morski in obalni ekosistem koprskega zaliva, ki ima zaradi plitvosti omejene samočistilne sposobnosti (Špes, 2001).

Prevladujoče antropogene pritiske na morski ekosistem povzročajo tudi dotoki površinskih voda. Rižana je onesnažena s komunalnimi, industrijskimi in kmetijskimi odplakami, Dragonja prinaša predvsem komunalne, Badaševica pa industrijske odplake. Ker obalna naselja v večini nimajo urejenega ustreznega čiščenja komunalnih odplak, te neposredno onesnažujejo morsko vodo. Agrarne emisije onesnažujejo vode s hranilnimi snovmi ter pesticidi. Antropogene pritiske na morski ekosistem povzroča tudi turizem, tako z odpadnimi vodami kot tudi preko izpustov iz plovil. Potencialno nevarnost predstavlja morski promet, 
saj lahko ob morebitni nesreči pride do izpusta olj, nafte in drugih škodljivih snovi (Špes, 2000).

Ker se na priobalni ravnici koncentrirajo številne dejavnosti (turizem, industrija, luške dejavnosti, promet) ter večina prebivalstva, doživlja ta kopenski ekosistem velike antropogene pritiske. Ogroža ga tudi intenzivna kmetijska raba, ki predstavlja nevarnost za onesnaževanje prsti, kopnih vodnih virov in morja. Drugi akutni in potencialni viri onesnaževanja voda so še odlagališča odpadkov, nevodotesno kanalizacijsko omrežje, neurejena gnojišča, cesta in železnica. Naravne samočistilne sposobnosti ozračja (dobra prevetrenost) in relativno manjši viri emisij omogočajo, da se obalno območje ne srečuje s prekomerno onesnaženostjo zraka. Narašča pa problem povečanih koncentracij ozona v poletnih mesecih (Špes, 2000).

\section{LUKA KOPER}

\section{Gospodarski pomen}

Slovenija je geografsko in prometno vpeta v osrčje Evrope, ki ima razvito prometno infrastrukturo in navezavo na prekomorske prometne poti, kar predstavlja prednost in priložnost. Naše edino pristanišče, koprsko luko, ki se danes razteza na 490 ha in na treh kilometrih obale, odlikuje izjemno ugodna geografska lega. Leži na točki, kjer se Jadran najbolj zajeda proti severu in predstavlja najkrajšo pot iz Sredozemlja v srednjo Evropo. Poleg tega se pristanišče navezuje na V. in X. panevropski koridor. Kar približno 70 \% blaga, ki ga pretovorijo v Luki, je prepeljanega po železnici (Letno poročilo 2003).

Graf 1: Rast skupnega ladijskega pretovora v Luki Koper med leti 1996 in 2005 (vir: Pretovor v letih 1996-2005, 2006)

Figure 1: Growth in common maritime cargo throughput in Luka Koper between 1996 and 2005.

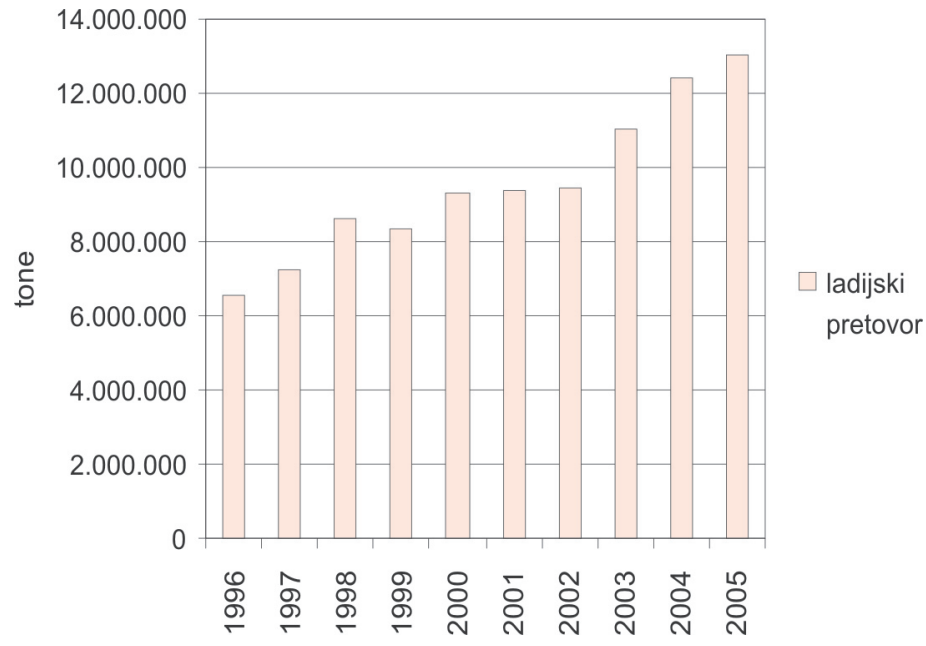


Za pristaniške in logistične storitve pristanišča skrbi Luka Koper, d.d, ki je eden izmed paradnih konjev slovenskega gospodarstva. Luka Koper predstavlja velik ekonomski potencial tako na regionalni kot na nacionalni ravni, saj ima velike multiplikativne učinke na razvoj celotnega slovenskega gospodarstva. Neposredno je povezana s podjetji kot so Slovenske železnice, Intereuropa, Viator\&Vektor, Primorje, SCT, Banka Koper, Revoz, OMV Istrabenz, Petrol in mnogimi drugimi.

V Luki Koper beležijo stalen porast količine pretovorjenega blaga. Leta 2000 je pretovor prvič presegel 9 milijonov ton, v letu 2003 je znašal že 11 milijonov, 2004 pa 12,4 milijone (Letno poročilo 2004). V letu 2005 so dosegli rekordni pretovor, in sicer 13 milijonov ton. Trend rasti pretovorjenega blaga narašča tudi v letošnjem letu. Marca 2006 je bil dosežen rekordni mesečni pretovor, ki znaša 1,4 milijona ton (Notice; april 2006).

\section{Okoljski vplivi Luke Koper}

Naraščajoči obseg prometa in velikost površin, ki jih pristanišče zaseda, kažeta na širok spekter okoljskih vplivov na obalni ekosistem. Med vplive Luke Koper na okolje se uvršča poraba naravnih virov, kot sta voda in pogonsko gorivo ter poraba prostora, nastajanje odpadne vode in odpadkov, emisije plinov in prahu v ozračje ter emisije hrupa. S pristaniškimi dejavnostmi je povezan ladijski promet, ki zaradi škodljivih snovi (nafta in derivati, različne kemikalije) predstavlja potencialno grožnjo ob morebitni nesreči. Na Luko Koper se veže tudi obsežen cestni in železniški promet, ki tudi predstavlja obremenitev okolja, hkrati pa zaradi nevarnih tovorov obstaja možnost hujših okoljskih nesreč (Cigale, 2000). Za nadzorovanje vplivov oziroma njihovo postopno zmanjševanje se s strani pristojnih institucij s pooblastilom Ministrstva za okolje in prostor redno opravljajo meritve parametrov zraka, vode in hrupa (Odnos do okolja, 2005).

Glavna vira emisij v zrak sta terminala razsutih in tekočih tovorov (Kvaliteta življenjskega..., 1998). Emisije plinov (CO, $\mathrm{NO}_{\mathrm{x}}$ ) iz dvanajstih kurilnih naprav na tekoče gorivo in utekočinjen naftni plin merijo na terminalu za tekoče tovore, kontrola vodnih izpustov se izvaja na terminalu za tekoče tovore in v obeh avtopralnicah, nadzor emisij prahu na terminalu za glinico, na terminalu za sipke tovore, na terminalu silos in na evropskem energetskem terminalu. Koncentracije in emitirane količine hlapov organskih topil merijo na terminalu tekočih tovorov. Redno se opravljajo mesečne meritve hrupa na treh mejnih točkah, na stičišču pristanišča z naseljenimi območji. Luka zmanjšuje delež mešanih odpadkov in kontrolira njihovo odlaganje. Delež ločeno zbranih odpadkov je leta 2004 znašal 78 odstotkov (Letno poročilo 2004).

Podatki o emisijah plinov, prahu in hrupa nam niso bili dostopni, zato smo se oprli na starejše vire in na letna okoljska poročila Luke Koper, ki pa navajajo precej skope podatke. Ti se praviloma nanašajo na tedenske in polletne koncentracije za prah ter na letne za hrup, medtem ko dnevne povprečne vrednosti, ki so najbolj problematične, niso navedene.

V Luki Koper trdijo, da dosegajo okoljske cilje, skladne z zahtevami Evropske unije. Izmerjene emisije prahu in hrupa naj bi bile pod zakonsko določenimi mejami. Polletna povprečna koncentracija inhalabilnega prahu v bližini deponije razsutih tovorov, ki znaša $27.9 \mu \mathrm{g} / \mathrm{m}^{3}$, je pod zakonsko določeno maksimalno koncentracijo $40 \mu \mathrm{g} / \mathrm{m}^{3}$ (Letno poročilo 
2004). Glede na to, da prah povzroča glavnino problemov predvsem v času vetrovnih vremenskih situacij, podatek o polletni povprečni koncentraciji ni relevanten, ker je preveč posplošen. Rezultatov meritev drugih parametrov v okoljskem poročilu ne navajajo.

Starejše meritve, ki jih je leta 1996 opravil Center za ekologijo, toksikologijo in varstvo pred sevanji iz Ljubljane, so pokazale, da so bile emisije trdih delcev pri pretovarjanju premoga in železove rude v skladu z Uredbo o emisiji snovi v zrak iz nepremičnih virov onesnaževanja. To je bilo mogoče doseči le ob zagotavljanju zadostne vlažnosti pretovorjenega materiala (Cigale, 2000). Okoljske vplive tako skušajo omiliti z vlaženjem deponije premoga in železove rude (preprečujejo pretirano dvigovanje prahu), ki je ekološko najbolj sporen tovor. Posadili so tudi zelene pasove drevesnega rastja (Kvaliteta življenjskega...,1998) ter 11 metrov visoko zaščitno steno na skrajnem severnem robu pristanišča, ki naj bi preprečevala širjenje prahu in drugih vplivov pristanišča ter poskrbela za lepši stik pristanišča z okolico.

V letih 1996 in 1997 so bile opravljene tudi meritve koncentracij in emisij hlapov organskih topil na terminalu tekočih tovorov, ki jih je opravil Zavod RS za varstvo pri delu. Pri rezervoarju z vinilacetatom ter pri polnjenju kamionskih cistern z etanolom so bile emisije hlapov glede na priporočila evropske smernice previsoke. Meritve na 12-ih kurilnih napravah na tekoče gorivo in utekočinjen naftni plin so pri dveh pokazale preseženo mejno emisijsko koncentracijo CO, ki znaša $250 \mathrm{mg} / \mathrm{m}^{3}$. Izmerili so 337 in $404 \mathrm{mg} / \mathrm{m}^{3}$. Mejna emisijska koncentracija $\mathrm{NO}_{\mathrm{x}}\left(260 \mathrm{mg} / \mathrm{m}^{3}\right.$ za male kurilne naprave), je bila presežena $\mathrm{v}$ treh primerih; izmerili so 337,328 in $263 \mathrm{mg} / \mathrm{m}^{3}$ (Špes in drugi, 1998). Vrednosti pri ostalih kurilnih napravah so bile bistveno manjše.

Luka Koper je zaradi velike površine in raznolikih dejavnosti velik potencialni onesnaževalec voda. Tehnološke odpadne vode nastajajo ob pranju avtomobilov in kontejnerjev, sten in tal skladišč ter pri pranju rezervoarjev za skladiščenje kemikalij. Sanitarne odpadne vode gredo $\mathrm{v}$ javno kanalizacijo, vode $\mathrm{z}$ manipulativnih površin pa se večinoma izpirajo $\mathrm{v}$ ustje Rižane in neposredno v morje. Tehnoloških in odpadnih voda je $180.000 \mathrm{~m}^{3}$ letno (Cigale, 2000).

Neposredne vplive pristaniških dejavnosti najbolj občutijo krajani v neposredni bližini pristanišča, in sicer krajani Sermina, Bertokov, Hrvatinov, Ankarana in Semedele. Največji okoljski problem po trditvah lokalnega prebivalstva predstavlja razsuti tovor. Ob vetrovnem vremenu, predvsem ko piha jugo, se prah iz deponije premoga vrtinči in prenaša do naselij, kjer se usedajo prašne obloge.

Onesnaževanje, ki ga povzroča luka, ni nepomembno, vendar praviloma ostaja v mejah zakonsko dopustnega obremenjevanja (Cigale, 2000). Konkretni podatki novejših meritev emisij pa nam niso bili dostopni.

\section{Načrtovana širitev Luke Koper}

Luka Koper trenutno razpolaga s Pomolom I in Pomolom II. Pretovor stalno narašča, zato se Luka želi širiti. Edino možnost širitve, zarisano v občinske planske dokumente že v 70-ih letih, predstavlja Ankaranski zaliv, kjer je načrtovana izgradnja Pomola III, kjer je že izkopana ustrezna globina. Pomol III bi bil namenjen pretovoru kontejnerjev, ki se trenutno opravlja na Pomolu I in deluje v dolžini $500 \mathrm{~m}$ z razpoložljivo površino pretovora $150000 \mathrm{~m}^{2}$. 
Obstoječa infrastruktura ter tehnološka oprema terminala omogočata največji letni pretovor 170.000 TEU (TEU je enota, na katero se preračunava promet in pomeni 1 kontejner dolžine 20 čevljev). Ker prav pretovor kontejnerjev najhitreje narašča, se po trditvah Luke, terminal približuje meji zmogljivosti. Pretovarjanje kontejnerjev, ki so finančno najdonosnejši tovor, želijo preseliti na nov kontejnerski terminal na Pomolu III, ki bi imel letno zmogljivost 450.000 TEU. S tem naj bi ostali konkurenčni ostalim severno jadranskim pristaniščem in povečali dobiček (Luški glasnik; posebna izdaja 2004).

Slika 1: Lokacija predvidenega tretjega pomola (Matos, 2005).

Picture 1. Location of the foreseen third pier.

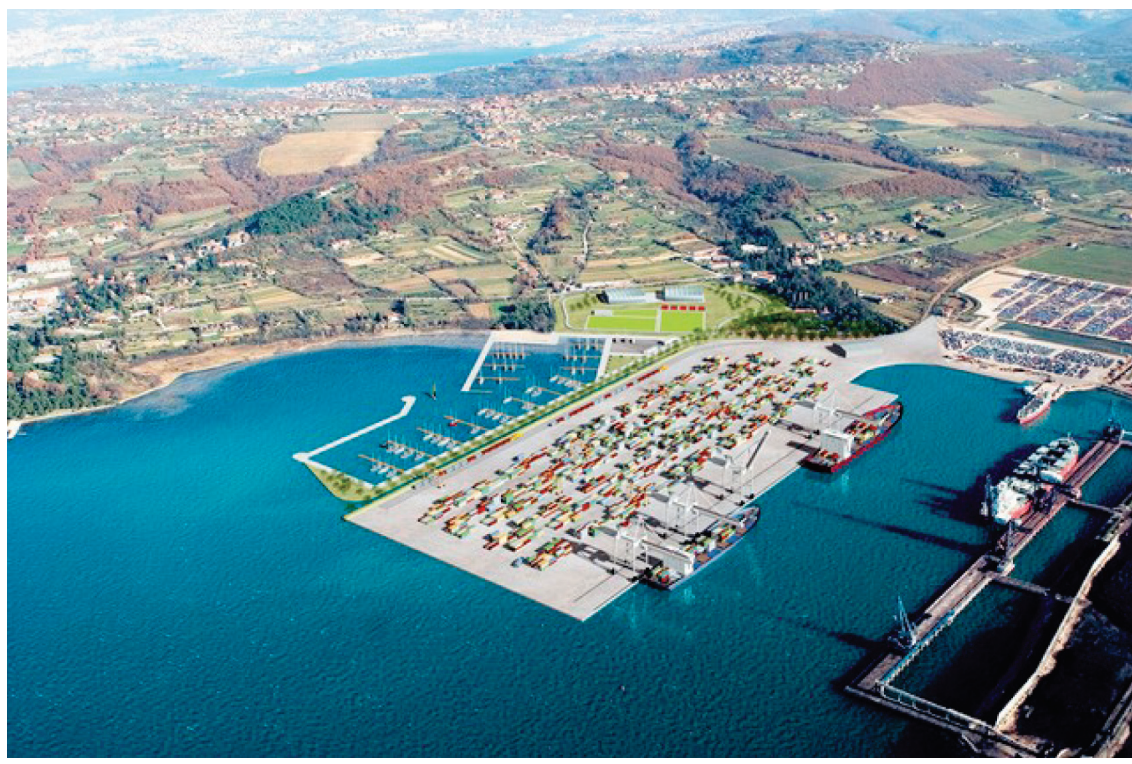

V postopku priprave lokacijske dokumentacije za tretji pomol je Vodnogospodarski inštitut iz Ljubljane leta 2001 pripravil Poročilo o vplivih na okolje. Študija navaja, da je na osnovi dotlej znanih podatkov izgradnja Pomola III in kontejnerskega terminala na njem z vidika obremenitev in sprememb okolja, ob upoštevanju okoljevarstvenih ukrepov, sprejemljiva (Luški glasnik; posebna izdaja 2004).

Odločitev o širitvi na tretji pomol ima sedaj v rokah Ministrstvo za okolje in prostor, ki pripravlja nov državni lokacijski načrt, znotraj katerega bo tudi celovita presoja vplivov na okolje.

Med določenim delom prebivalstva koprske občine se je do predvidene širitve pristanišča oblikoval izrazito negativen odnos. V krajevni skupnosti Ankaran so se nasprotniki gradnje tretjega pomola združili v iniciativni odbor proti širitvi. Poudarjajo predvsem, da je rešitev problema v racionalnejši izrabi obstoječih površin ter da bi morala Luka Koper več vlagati v okoljsko sanacijo, predvsem na terminalu razsutih tovorov. 


\section{PREDSTAVITEV PREUČEVANJA ODNOSA OBČANOV DO LUKE KOPER}

$\mathrm{Z}$ reprezentativnim vzorcem anketiranja smo želeli ugotovit, kakšen je dejansko odnos prebivalcev Mestne občine Koper do Luke Koper, saj so le-ti z njim najbolj povezani in jih okoljski vplivi luke najbolj zadevajo.

Karta 1: Območje Mestne občine Koper, razdeljeno na štiri delovna obmoçja

Map 1: Koper community divided into four working regions.

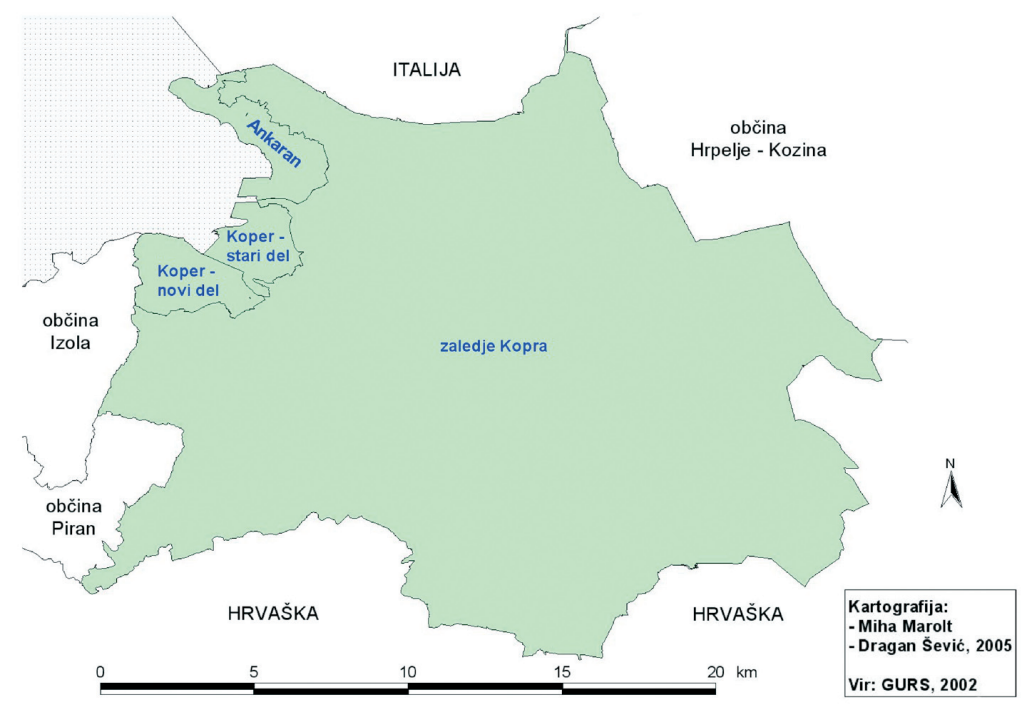

(kartografija: Marolt in Ševič, 2005, vir: GURS, 2002).

Opravili smo 831 anket. Poleg podatkov o anketirancu je anketa vsebovala štiri sklope vprašanj. Nanašala so se na oceno kvalitete bivalnega okolja na splošno, oceno vpliva pristanišča na kvaliteto bivalnega okolja, na spremljanje in vire informacij o delovanju Luke Koper ter na odnos do načrtovane širitve koprskega pristanišča.

Za potrebe vzorčenja smo Mestno občino Koper razdelili na: Koper novi del, Koper stari del, Ankaran ter zaledje. Anketirali smo znotraj teh enot, ki smo jih še nadalje razdelili na okoliše. Anketirali smo po združenih dejanskih popisnih okoliših. Želeli smo zajeti mnenje približno vsakega 30. prebivalca v naseljih Koper, Ankaran ter v Bertokih. Posamezen okoliš je imel približno 800 prebivalcev, med katerimi je bilo opravljenih povprečno 15 anket. Zaledje je imelo manjši vzorec.

$78 \%$ anket je bilo izvedeno v Kopru in $13 \%$ v Ankaranu, $9 \%$ pa v zaledju. Tako smo dali največjo težo odgovorom prebivalcev v najbližjem zaledju luke ter hkrati zajeli mnenja širšega zaledja oziroma celotne občine. 


\section{Značilnosti anketirancev}

Struktura anketirancev je bila glede na spol relativno uravnotežena - tako je bilo med 831 anketiranci $53,5 \%$ žensk in $46,5 \%$ moških.

Glede na starost smo anketirance razdelili v 4 starostne razrede - in sicer starostni razred do 20 let ("mladi"), 21 do 40 let, 41 do 60 let ter starostno skupino nad 60 let ("starejši"). Najbolje je bila zastopana tretja starostna skupina (37,8 \%), najslabše pa mladi (5,6 \%). Ostali dve skupini, 21- 40 in nad 60 let obsegata približno enak delež vprašanih (29,4 \% in 27,3\%).

Med anketiranci so največji delež predstavljali srednješolsko izobraženi (48,6\%), sledili so visoko in višješolsko izobraženi $(24,3 \%)$ in anketiranci z dokončano osnovno šolo $(15,9 \%)$. V anketi smo obravnavali še dve kategoriji, kategorijo "'brez izobrazbe" $(2,4 \%)$ ter "poklicna izobrazba" (8,7\%).

Več kot polovica vseh anketirancev $(51,3 \%)$ še ni, ni več ali pa ni zaposlena v nobeni od izpostavljenih gospodarskih panog (šolarji, dijaki in študenti, brezposelni, upokojenci, kmetje itd.). Med zaposlenimi v izpostavljenih gospodarskih panogah, industrija, promet, turizem, trgovina in storitve ter kvartarne dejavnosti, je največ anketirancev zaposlenih v trgovini in storitvah $(17,4 \%)$, sledijo kvartarne dejavnosti (15,3\%), industrija $(9,9 \%)$, turizem $(3,2 \%)$ in promet $(3,1 \%)$.

Velika večina anketirancev na današnji lokaciji stanuje že več kot 15 let. Takšnih je $74,6 \%$, obe drugi skupini, do 5 let in od 5 do 10 let, zavzemata mnogo manjši delež, nekaj nad $10 \%$. Sklepamo lahko, da je velika večina anketirancev že dalj časa izpostavljena vplivom koprskega pristanišča, kakšni so le-ti, v kolikšni meri jih ljudje zaznavajo, pa smo povprašali $\mathrm{v}$ jedru anketnega vprašalnika.

Anketirance smo povprašali tudi, če so sami ali kdo od družinskih članov neposredno ali posredno povezanih z Luko Koper, oziroma če so zaposleni v podjetjih, ki so neposredno vezana na delovanje pristanišča. Neposredno je z Luko Koper povezanih 16,6 \%, posredno pa $13,9 \%$ vprašanih. Med njimi smo pričakovali več tolerance do okoljskih vplivov ter do načrtovane širitve pristanišča.

\section{Ocena kvalitete bivalnega okolja}

Več kot polovica anketiranih (59 \%) ocenjuje okolje kot čisto in urejeno. Ostalih $41 \%$ moti predvsem onesnažen zrak, hrup in prah. Najbolj zadovoljni so s svojim bivalnim okoljem prebivalci zaledja, več nezadovoljnih je v neposredni bližini pristanišča. Največji delež nezadovoljnih (med 81 in $100 \%$ ) je v Ankaranu.

Prebivalci na različnih območjih občine Koper zaznavajo podobne okoljske probleme. Najbolj izpostavljajo onesnažen zrak (23\%), prah (15\%) in hrup (20 \%). Največje razlike med obravnavanimi območji občine (Koper novi in stari del, Ankaran in zaledje) se kažejo $\mathrm{v}$ deležu vprašanih, ki zaznavajo problem onesnaženih voda. Teh je največ v Ankaranu, kjer $17 \%$ ljudi, ki so nezadovoljni z bivalnim okoljem, kot moteč okoljski problem navajajo onesnažene vode. $\mathrm{V}$ drugih treh območjih je ta delež pod $10 \%$. V zaledju so bili odgovori o motečih okoljskih problemih najbolj raznoliki (Graf 2). 
Karta 2: Prostorska diferenciacija in koncentracija negativnih mnenj o kvaliteti bivalnega okolja (kartografija: Marolt in Ševič, 2005).

Map 2: Space differenciation and concentration of negative opinions about the quality of everyday environment.

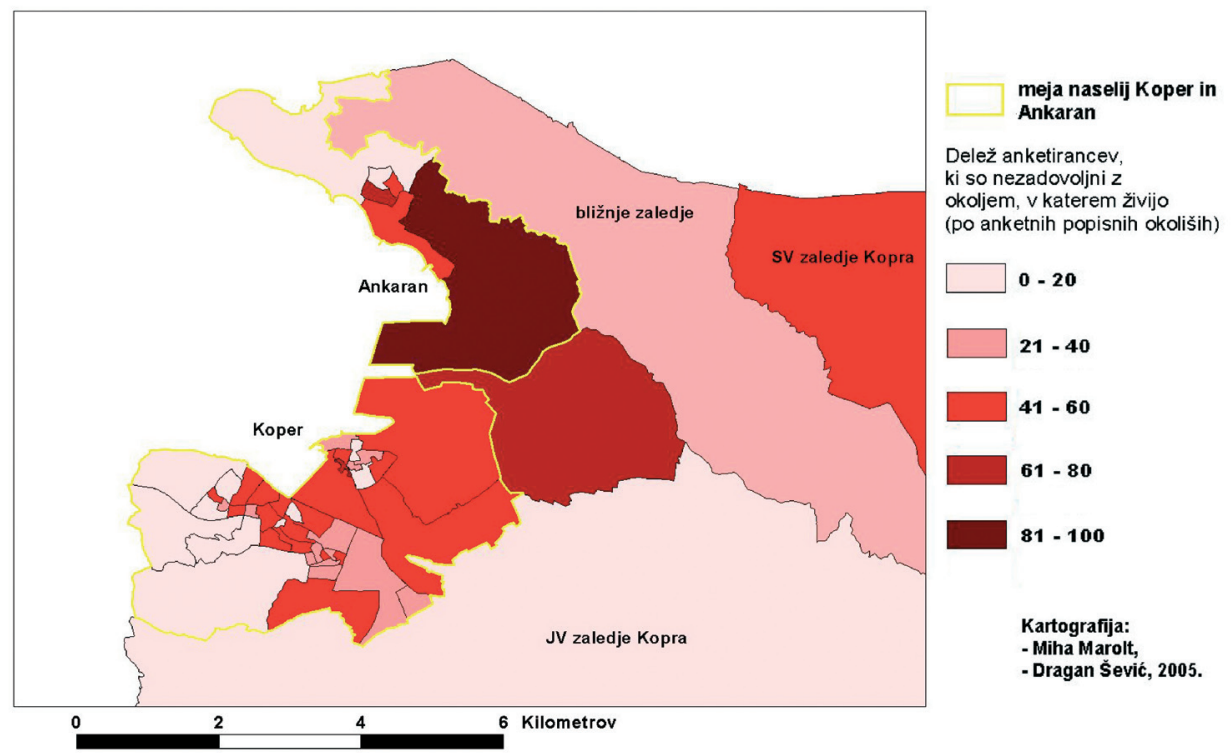

Graf 2: Moteči elementi, ki jih zaznavajo občani v določenih delih občine.

Figure 2: Disturbing elements perceived by citizens in different regions of Koper community.

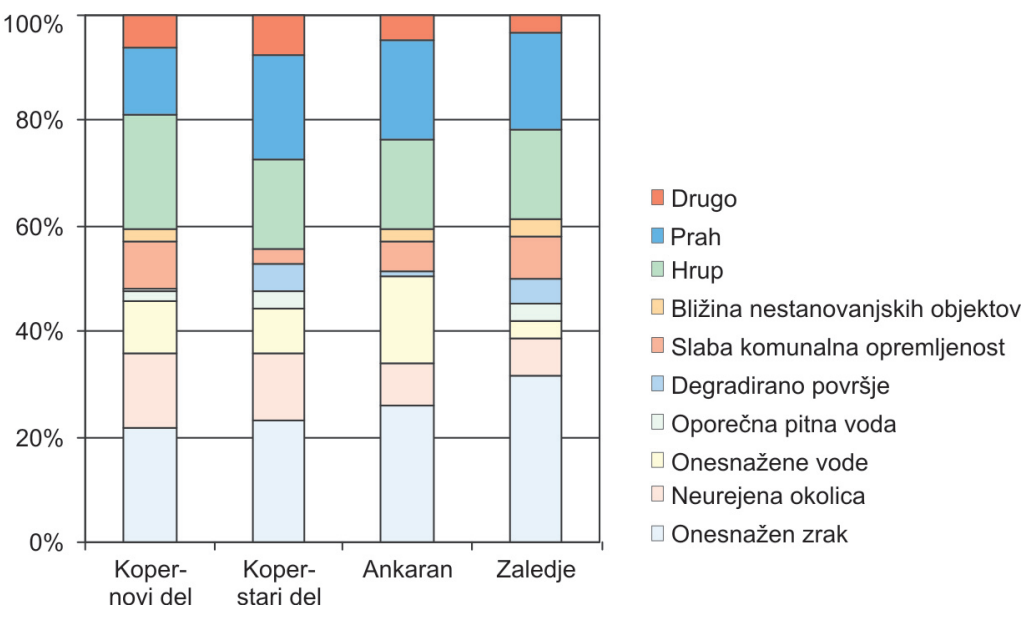




\section{Ocena vpliva luke Koper na kvaliteto bivalnega okolja}

Če smo v prvem sklopu vprašanj želeli zajeti mnenja o onesnaženosti bivalnega okolja na splošno, se je drugi sklop vprašanj že konkretno nanašal na vplive koprskega pristanišča.

Graf 3: Ocena vplivov koprskega pristanišča na bivalno okolje.

Figure 3: Evaluation of port impacts upon everyday environment.

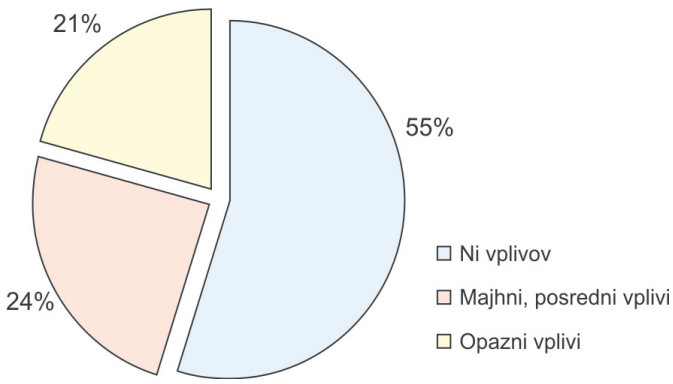

Dobra polovica anketirancev (55\%) negativnih vplivov na svoje bivalno okolje s strani pristanišča ne zazna. Kljub vsemu pa dobra petina vprašanih meni, da so vplivi luke opazni.

Graf 4: Ocena vplivov koprskega pristanišča na bivalno okolje po različnih območjih.

Figure 4: Evaluation of port impacts upon everyday environment in different regions of Koper community.

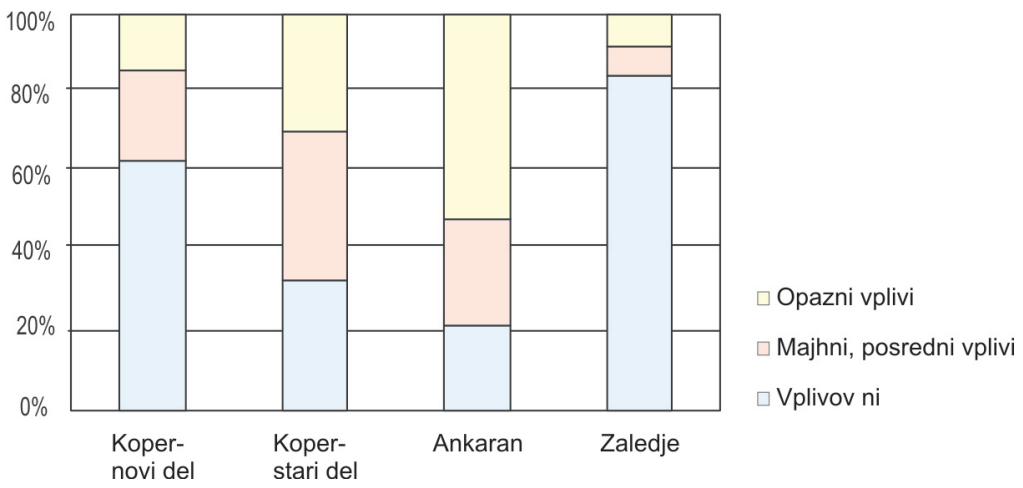

Delež anketirancev, ki menijo, da Luka Koper ne vpliva na bivalno okolje, je daleč največji v zaledju. S prostorskim približevanjem Luki Koper to mnenje strmo upada. Tako so predvsem prebivalci območja Ankaran in območja Koper - stari del prepričani, da vplivi Luke Koper na bivalno okolje vsekakor obstajajo. 50 \% vprašanih na območju Ankarana meni, da so le-ti opazni. V enoti Koper - stari del tako trdi slabih 30 \% vprašanih.

Za kartografsko ponazoritev smo izločili anketirance, ki so menili, da ima Luka negativne vplive na bivalno okolje in prikazali, kolikšen delež vprašanih po anketnih popisnih 
okoliših je zaznal bodisi zgolj majhne in posredne bodisi opazne negativne vplive luke na svoje bivalno okolje. Največji delež anketiranih, ki meni, da ima luka negativne vplive, je v neposredni bližini pristanišča (Karta 3).

Karta 3: Mnenje anketirancev o okoljskih vplivih Luke Koper na bivalno okolje; diferenciacija mnenj, da ima pristanišče negativne vplive (kartografija: Marolt in Ševič, 2005).

Karta 3: Differenciation of opinion about negative port impacts.

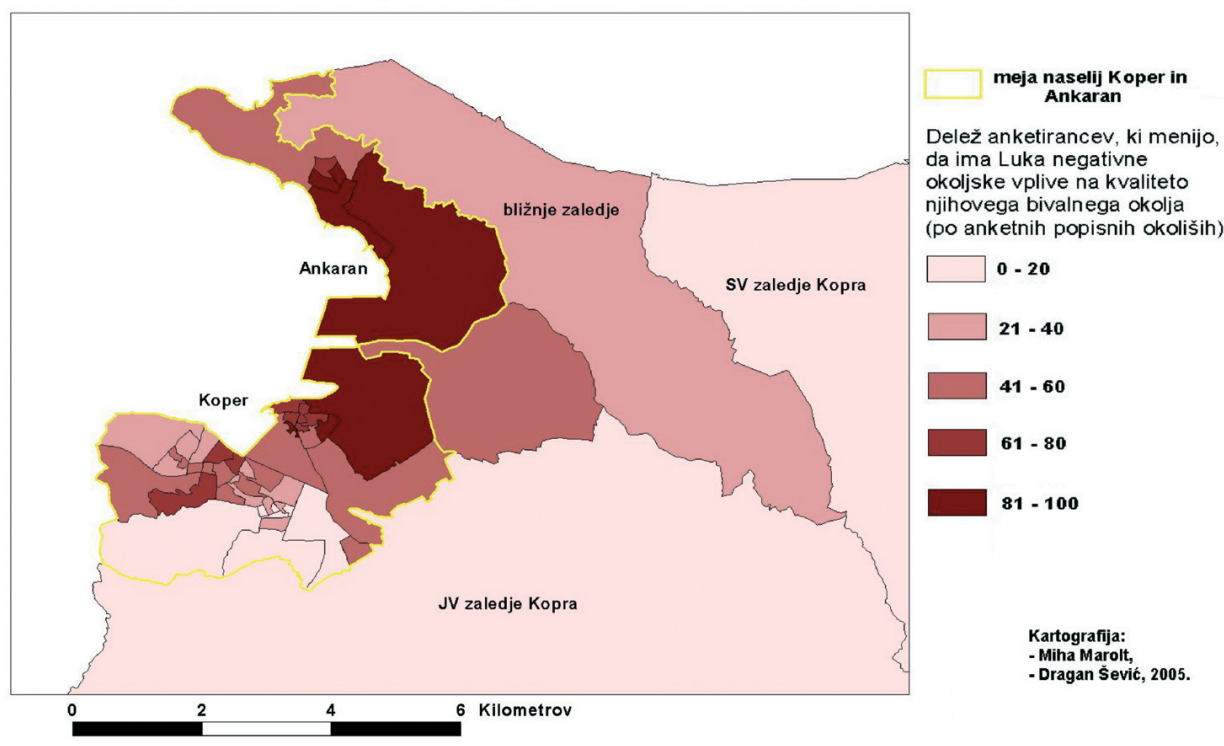

Nadalje smo z dvema razredoma (0-75 \% in nad $75 \%$ tistih, ki menijo, da so negativni vplivi opazni), prikazali, kje so okoljski vplivi luke najbolj izraziti (Karta 4). Zelo nazorno se zopet izriše območje v neposredni bližini pristanišča. Tu več kot $75 \%$ tistih, ki menijo, da pristanišče ima negativne vplive na bivanjsko okolje, trdi, da so le-ti opazni in ne zgolj majhni in posredni.

Z višanjem dosežene stopnje izobrazbe raste tudi kritičnost do vplivov pristanišča na bivalno okolje. Če ljudje brez ali z osnovno ter poklicno stopnjo izobrazbe še večinoma menijo, da koprsko pristanišče večjih vplivov na okolje nima, se z njimi strinja le približno $50 \%$ ali celo manj anketirancev, ki imajo dokončano srednjo šolo ali pa višjo oziroma visoko šolo. Potrebno je poudariti, da v zadnjih dveh omenjenih kategorijah raste tako delež tistih, ki menijo da so ti vplivi majhni in posredni, kot tistih, ki menijo, da so vplivi opazni.

Do vplivov pristanišča na bivalno okolje so najbolj kritični anketiranci, zaposleni v kvartarnih dejavnostih. Zanimivo je, da večina vprašanih, ki je zaposlena v turizmu in so mnenja, da vplivi Luke na bivalno okolje vendarle obstajajo, meni, da so le-ti majhni in posredni. Največ anketirancev (okrog 60 \%), ki menijo, da pristanišče na bivalno okolje nima vpliva, je zaposlenih v industriji in prometu. Ker sta obe panogi tesno povezani s pristaniško 
dejavnostjo, lahko upravičeno sklepamo, da so ti anketiranci posredno ali neposredno odvisni od Luke Koper in so do njenih okoljskih vplivov posledično bolj tolerantni.

Karta 4: Mnenje anketirancev o okoljskih vplivih Luke Koper na bivalno okolje; diferenciacija mnenj, da ima pristanišče opazne negativne vplive (kartografija: Marolt in Ševič, 2005).

Karta 4: Differenciation of opinion about observable negative impacts of the port.

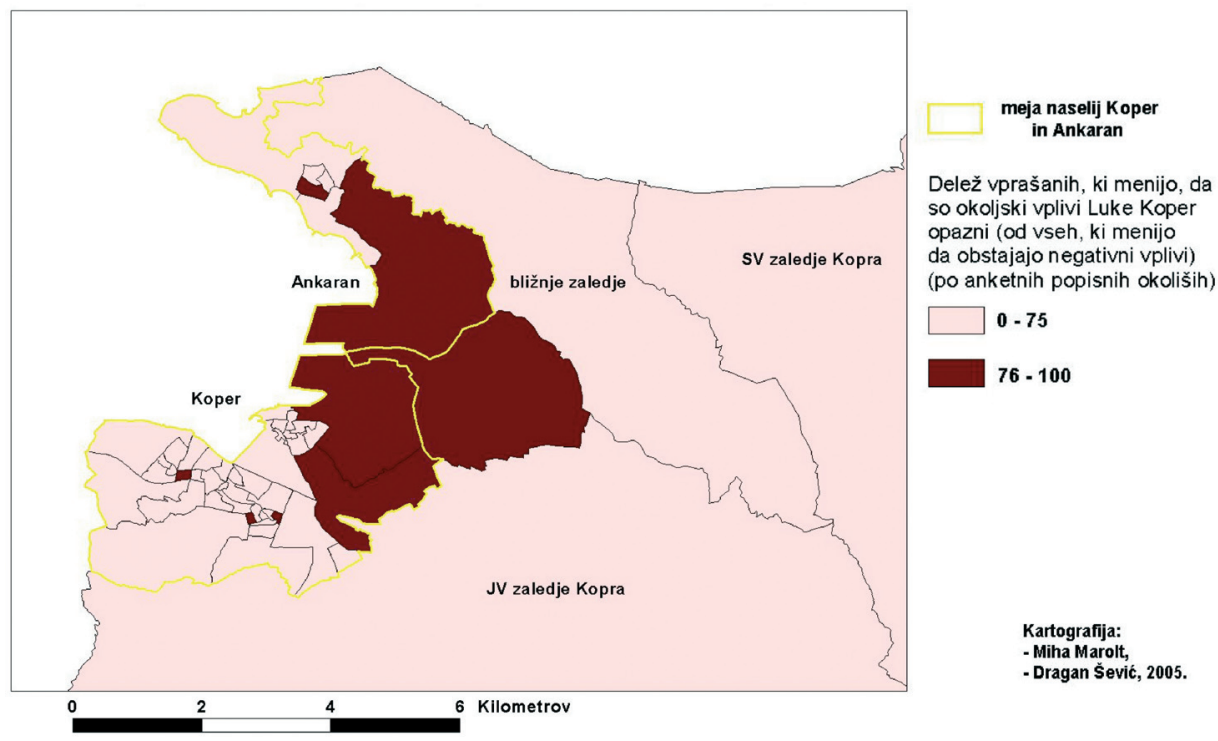

Graf 5: Vplivi Luke Koper na kvaliteto bivalnega okolja.

Graf 5: Impacts of Luka Koper upon the quality of everyday environment.

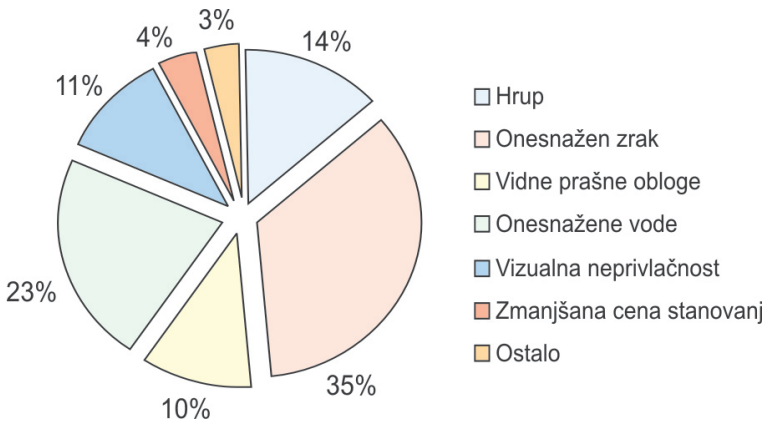

Med različnimi negativnimi okoljskimi vplivi pristanišča so anketiranci izpostavili predvsem onesnažen zrak, onesnažene vode ter v približno enakem deležu še hrup, vizualno neprivlačnost ter vidne prašne obloge. 
Graf 6: Vplivi pristanišča na kvaliteto bivalnega okolja po različnih območjih občine Koper. Graf 6: Impacts of Luka Koper upon the quality of everyday environment in different regions of Koper community.

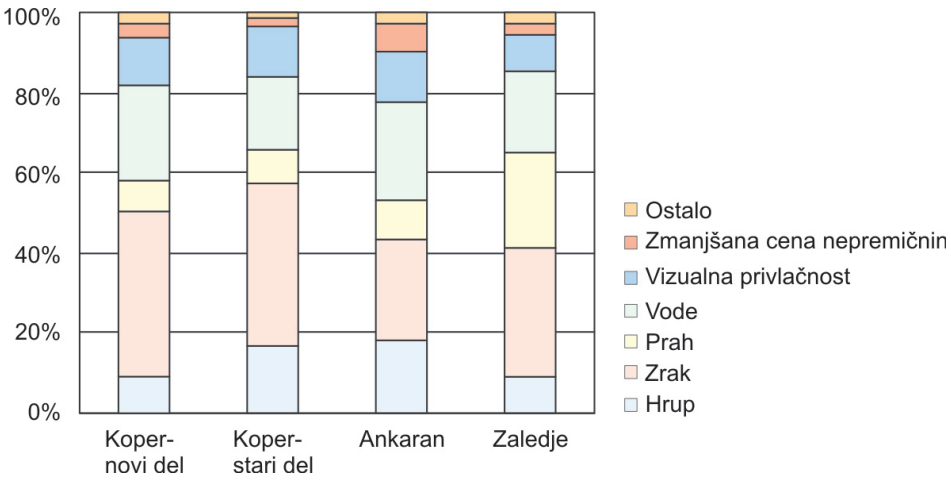

Hrup predstavlja največji problem predvsem v bližini pristanišča, v starem delu Kopra ter v Ankaranu. Nad onesnaženim zrakom se v največji meri pritožujejo predvsem anketiranci v Kopru. V zaledju so v primerjavi z ostalimi območji občine najbolj poudarili problem prahu, ki je najbolj izrazit ob močnejšem vetru ter slabem vremenu. Vizualna neprivlačnost moti predvsem vprašane v obalnem pasu, medtem ko Ankarančane moti tudi zmanjšana cena nepremičnin, oziroma strah pred tem.

Graf 7: Ocene pomena Luke Koper.

Graf 7: Evaluation of the importance of Luka Koper.

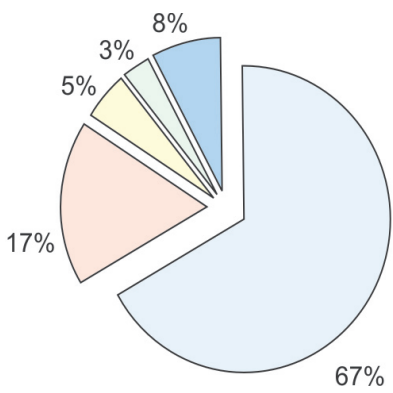

Pozitivno

Ne glede na vse, mora Slovenija

ohraniti edino pristanišče

$\square$ Negativni okoljski vplivi prevladujejo

nad pozitivnimi gospodarskimi

Negativno - obalni pas bi morali

nameniti drugim dejavnostim

Drugo

Kar $67 \%$ anketiranih ima o pomenu koprskega pristanišča pozitivno mnenje, $17 \%$ jih kljub zapletom podpira pristaniško dejavnost, kar je skupaj $84 \%$ anketiranih, ki so kakorkoli naklonjeni Luki Koper. Nasproti 3 \% vprašanih meni, da bi moral biti obalni pas namenjen drugim dejavnostim, predvsem turizmu, $5 \%$ jih poudarja negativne okoljske vplive, ki naj ne bi odtehtali gospodarskega pomena pristanišča. Negativen odnos se tako pojavlja pri $8 \%$ vprašanih, medtem ko se v naslednjih 8-ih odstotkih, ki so se opredelili za kategorijo »drugo«, skrivajo deljena mnenja ter neopredeljeni. 
Zanimiva je diferenciacija mnenj o pomenu pristanišča med zaposlenimi v različnih dejavnostih. $77 \%$ zaposlenih na področju prometa pristaniško dejavnost ocenjuje izključno pozitivno, medtem ko je takih, zaposlenih v turizmu, $52 \%$. Dejavnosti, ki so neposredno povezane z Luko Koper in so od nje tudi eksistenčno odvisne, njen pomen ocenjujejo bolj pozitivno. Nihče izmed vprašanih, ki so zaposleni v prometu, nima negativnega stališča do Luke Koper.

Graf 8: Ocene pomena Luke Koper glede na zaposlitveno strukturo.

Graf 8: Evaluation of the importance of Luka Koper as regards employment structure.

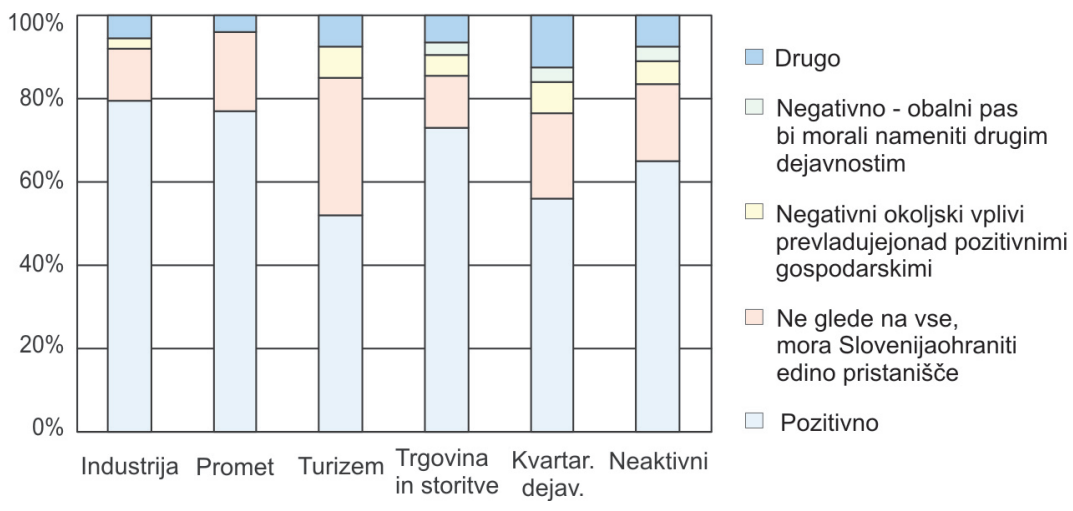

\section{SPREMLJANJE IN VIRI INFORMACIJ O LUKI KOPER}

Graf 9: Sledenje informacijam o delovanju Luke Koper.

Graf 9: Tracking of information about Luka Koper.

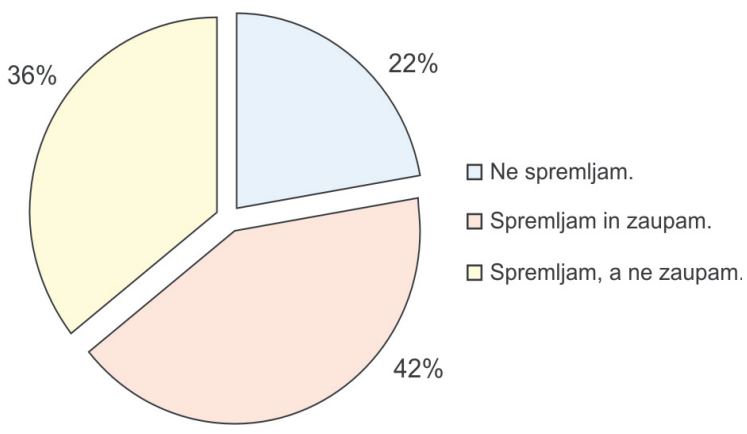

Na vprašanje "Ali spremljate informacije o delovanju Luke Koper?" je $78 \%$ anketirancev odgovorili pritrdilno. Slednje smo dodatno povprašali, če zaupajo prejetim informacijam. Dokaj visok delež anketirancev je o delovanju Luke Koper obveščen, vendar dobra tretjina 
prejetim informacijam ne zaupa. Ta podatek je lahko zaskrbljujoč, saj kaže na dobršno mero nezaupanja občanov do Luke.

Predvsem mladi informacij o pristanišču ne spremljajo (59\% mladih). Vse ostale starostne skupine približno enako spremljajo informacije (približno v 80-ih \%) in jim tudi približno enako zaupajo (v 40-ih \%). Z doseženo stopnjo izobrazbe se informiranost anketirancev viša.

\section{Graf 10: Glavni viri informacij o Luki Koper.}

Graf 10: Main source of information about Luka Koper.

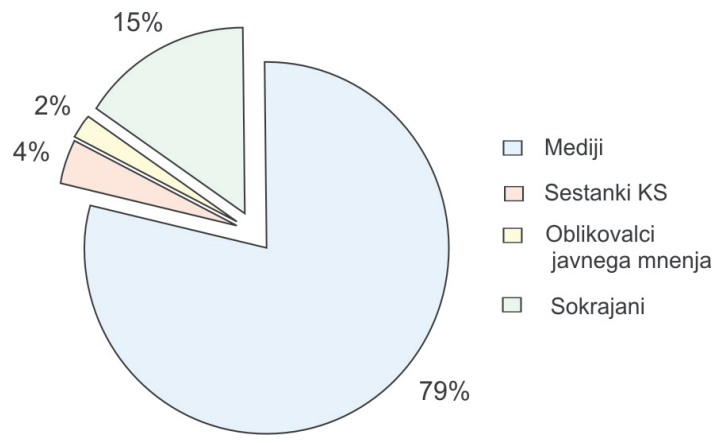

V veliki meri kot glavni vir informacij vsekakor prevladujejo mediji, kot vir informacij večjega vpliva se pojavljajo tudi sokrajani.

\section{ODNOS DO GRADNJE TRETJEGA POMOLA LUKE KOPER}

Graf 11: Odnos občanov do širitve Luke Koper.

Graf 11: Relation of citizens to the extension of Luka Koper.

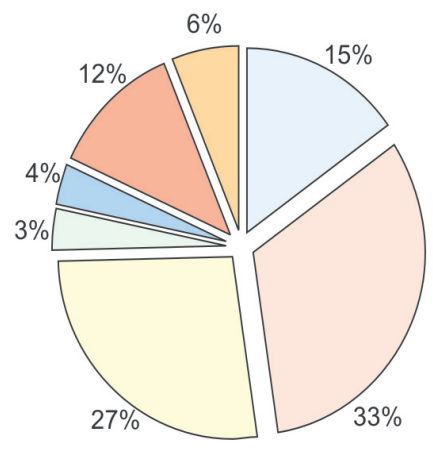

\footnotetext{
$\square$ Do tega posega se nisem opredelil.

$\square$ Menim, da je novogradnja nujna za nadaljevanje in širjenje luških dejavnosti

$\square$ Gradnjo pogojno podpiram ob upoštevanju vseh ekoloških omejitev ter ob predhodni sanaciji dosedanjih negativnih učinkov

$\square$ Gradnjo pogojno podpiram, če bodo neposredno prizadeti prebivalci dobili finančno nadomestilo

$\square$ Bolj se zavzemam za iskanje drugih rešitev

$\square$ Nasprotujem gradnji pomola

$\square$ Drugo
}

Med vsemi anketiranimi je $15 \%$ neopredeljenih, teh delovanje pristanišča ne zanima. Tretjina podpira širitev Luke Koper in njenih dejavnosti ter meni, da je ta nujna. Gradnjo 
pogojno podpira naslednja tretjina (27 \% ob sanaciji negativnih okoljskih učinkov, $3 \%$ ob denarni odškodnini). $12 \%$ anketiranih gradnji nasprotuje (106 anketiranih od 831, od tega 37 Ankarančanov). Prebivalci se zavzemajo tudi za druge rešitve (4 \%); anketirani so navajali predvsem reorganizacijo dejavnosti znotraj obstoječih pomolov, najem pomola v sosednjih pristaniščih idr. Če povzamemo: 63 \% vprašanih širitev kakorkoli podpira, 22 \% ji nasprotuje, $15 \%$ je neopredeljenih.

Graf 12: Odnos občanov do gradnje tretjega pomola Luke Koper po različnih območjih občine. Graf 12: Relation of citizens to the building of the third pier in different regions of Koper community.

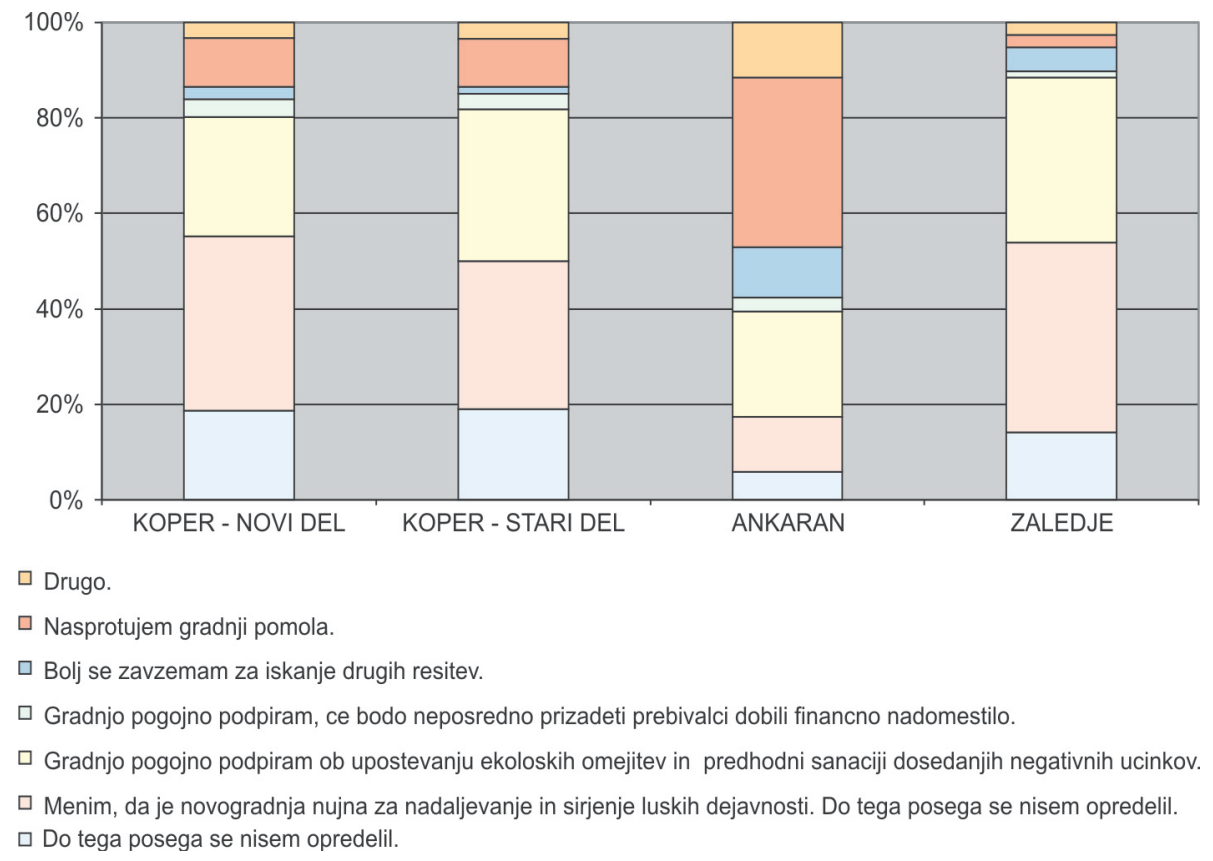

Širitvi pristanišča najbolj nasprotujejo v Ankaranu (36 \%), brezpogojna podpora širitvi je najbolj izrazita v zaledju (dobra tretjina vprašanih), kakorkoli (pogojno in brezpogojno) pa širitev podpira več kot polovica vprašanih na vseh območjih, razen v Ankaranu. Tu se odnos do širitve v primerjavi z ostalo občino zelo razlikuje. 12 anketiranih (od 103. vprašanih) gradnjo brezpogojno podpira, nadaljnjih 26 jo podpira pogojno. Kakršna koli podpora širitvi je torej 37 - odstotna. Zanimivo je, da bi renta bi zadovoljila le 3 anketirane, kar je podobno povprečju za celotno občin.

Z višjo izobrazbo brezpogojna podpora gradnji upada, delež tistih, ki se za gradnjo zavzemajo ob ekološki sanaciji negativnih učinkov luke pa je po izobrazbeni in zaposlitveni strukturi podoben (približno $30 \%$ ). 
Najbolj gradnji nasprotujejo zaposleni v turizmu ( $22 \%$ vprašanih), ki bi obalni pas namenili drugim dejavnostim. Med zaposlenimi v prometu širitvi ne nasprotuje nihče, 85 \% jo kakorkoli podpira, kar je največ med vsemi panogami.

Vprašani večinoma menijo, da je širitev koprskega pristanišča v interesu države ter da je leta lobistično premočna, da bi lahko prebivalci odločilno vplivali na razplet. Tako jih $82 \%$ meni, da pomol bodo gradili, od tega četrtina meni, da z zakasnitvijo, samo $5 \%$ pa trdi, da pomola ne bodo gradili. Med Ankaranom in ostalimi popisnimi območji v tem primeru ni razlik.

\section{SKLEPI}

Luka Koper je nedvomno izredno uspešna slovenska družba, ki beleži stalno prihodkovno rast in večanje obsega pristaniških ter logističnih storitev. Na regionalnem nivoju je pomembna predvsem kot neposredni delodajalec, posredno pa je od Luke Koper odvisnih še mnogo podjetij. Vizija edinega slovenskega pristanišča je postati vodilni logistični, distribucijski in transportni sistem za države srednje in vzhodne Evrope (Letno poročilo 2004). Izjemen gospodarski, prometni in gravitacijski pomen pristanišča pa se na drugi strani sooča z vplivi pristaniške dejavnost na okolje. Obalni ekosistem je na območju plitvega Koprskega zaliva še posebej občutjiv. Tu se stikajo interesi pristaniške dejavnosti, turizma in želje prebivalcev po čimbolj čistem okolju.

S projektom Odnos prebivalcev Mestne občine Koper do Luke Koper smo s pomočjo anketiranja prikazali, kakšen je dejanski odnos do Luke Koper med prebivalci Mestne občine Koper, v kolikšni meri Luko Koper pojmujejo kot onesnaževalca ter kako se odzivajo na njeno načrtovano širitev.

Izrazito odklonilno se je do pristanišča opredelilo $8 \%$, pozitivno pa kar $84 \%$ občanov. V večini se torej zavedajo velikega gospodarskega pomena pristanišča tako za občino kot tudi za samo državo, zato so do njegovih okoljskih vplivov tudi bolj tolerantni.

$\mathrm{Na}$ ravni celotne občine opazne vplive pristanišča na okolje zaznava petina vprašani, samo v Ankaranu jih opazne vplive zaznava polovica. To je razumljivo, saj s približevanjem pristanišču stopnja zaznavanja vplivov raste. Kritičnost do vplivov pristanišča na bivalno okolje rast tudi $z$ višanjem dosežene stopnje izobrazbe. Pomen Luke Koper najbolj pozitivno ocenjujejo zaposleni v dejavnostih, ki so z njo najbolj povezane (promet in industrija).

Občani v večini (78 \%) spremljajo informacije o delovanju Luke Koper, vendar jim kar tretjina vprašanih ne zaupa. Anketiranci so večkrat poudarili, da naj Luka svojih obljub občanom ne bi vestno izpolnjevala.

Srčika problema, ki smo ga želeli osvetliti, je odnos do načrtovane širitve Luke Koper. Podpira jo $63 \%$ občanov, od tega $33 \%$ brezpogojno. Proti širitvi je dobra petina vprašanih. Med 831 anketiranimi gradnji tretjega pomola nasprotuje 106 vprašanih, med njimi 37 Ankarančanov. Kakršnakoli podpora je visoka na vseh obravnavanih območjih (Koper novi in stari del ter zaledje), razen v Ankaranu, kjer širitev podpira tretjina vprašanih.

Odnos Ankarančanov do širitve Luke Koper je v primerjavi z ostalimi območji izrazito drugačen. Kljub temu med vprašanimi Ankarančani nasprotovanje širitvi ne prevladuje izrazito, saj je le to skoraj izenačeno s popolno in pogojno podporo širitvi. Razumljivo je, da 
Ankarančani na širitev gledajo drugače kot ostali občani, saj jih najbolj neposredno zadeva. Vendar negativni odnos do koprskega pristanišča in njegove širitve ni tako prevladujoč, da bi ga lahko, na podlagi opravljenih anket, posplošili na celotno območje krajevne skupnosti.

Tisti, ki so proti gradnji tretjega pomola, so najpogosteje kot razlog nasprotovanja navedli vplive pristanišča na okolje, ki jih do sedaj niso reševali v zadostni meri. Menijo tudi, da zaradi vse večje okoljske ozaveščenosti ljudje bolj zaznavajo negativne vplive na okolje.

Odnos občanov do Luke Koper torej na splošno ni odklonilen. Velik gospodarski pomen Luke na regionalnem nivoju veča toleranco občanov do njenih okoljskih vplivov. Vendar bi Luka Koper za varovanje okolja lahko storila še več, kar so omenili številni vprašani. Poudarjali so tudi, da širitev pristanišča ne predstavlja glavnega problema. Razsuti tovor in z njim povezane emisije prahu so po njihovem mnenju srčika negativnega odnosa nekaterih občanov, tudi Ankarančanov. Problemu bi morali po našem mnenju v Luki Koper posvetiti še posebno pozornost ter postopoma zmanjševati količino razsutega tovora, ki poleg je poleg ekološke spornosti tudi najmanj finančno donosen tovor. Čeprav se povprečne tedenske koncentracije prahu gibljejo $\mathrm{v}$ dovoljenih mejah, so ključni problem povprečne dnevne vrednosti, za katere konkretnih podatkov sicer nismo dobili, sklepamo pa, da večkrat presežejo dovoljene vrednosti.

\section{Sodelavci pri projektu}

Pri raziskovalnem projektu Odnos prebivalcev Mestne občine Koper do Luke Koper so pod mentorstvom dr. Metke Špes sodelovali študentje 4. letnika geografije, študijska usmeritev Varstvo geografskega okolja: Jurij Dobnik, Saša Dolinšek, Polona Ferjančič, Petra Holc, Janja Koren, Miha Marolt, Janez Matos, Jure Niedorfer, Maja Petrović, Mateja Pirc, Katarina Polajnar, Primož Skrt, Matej Simčič, Klemen Strmšnik, Dragan Ševič, Jana Tomažič in Maja Zupančič.

Pri dvodevnem terenskem delu so sodelovali tudi študentje 4. letnika z drugo študijsko usmeritvijo in študentje 3. letnika s prvo študijsko usmeritvijo Varstvo geografskega okolja ter asistentka mag. Katja Vintar Mally, dr. Dušan Plut in dr. Metka Špes.

\section{Viri in literatura:}

Cigale, D., 2000. Okoljske obremenitve in stanje okolja na obalnem območju - primer Koprskega primorja. Geographica Slovenica 33/1, str. 71 - 116.

Letno poročilo 2003. URL: http://www.luka-kp.si/publikacije/porocilo2003/lp_index_slo.html (citirano 28.3.2005)

Letno poročilo 2004. URL: http://www.luka-kp.si/publikacije/porocilo2004/lp_index_slo.html (citirano 11.6.2005)

Matos, U., 2005. Fotografija predvidene lokacije tretjega pomola. URL: http://www.mladina. si/tednik/200452/clanek/slo--obala-ursa matos/ (citirano 17.3.2005)

Notice; april 2006. URL: http://www.luka-kp.si/vsebina.asp?IDpm=58 (citirano 3.5.2006)

Odnos do okolja, 2005. URL: http://www.luka-kp.si/vsebina.asp?IDpm=16 (citirano 10.6.2005) 
Plut, D., 2004. Geografske metode proučevanja degradacije okolja. Ljubljana, Oddelek za geografijo, $188 \mathrm{str}$.

Popis 2002. URL: http://www.stat.si/popis2002/si/_(citirano 9.5.2006)

Potočnik, B., 2001. Pollution hot spots and sensitive areas along the Slovenian coast. Annales, Series historia naturalis, Letn. 11, št. 25.

Pretovor v letih 1996 - 2005. URL: http://www.luka-kp.si/vsebina.asp (citirano 10.5.2006)

Rejec Brancelj, I., 1994. Agrarnogeografska problematika Koprskega primorja z vidika varstva okolja. Geographica Slovenica 26/2.

Špes, M., Hočevar, M., Lampič, B., Skobir, M., Smrekar, A., 1998. Kvaliteta življenjskega okolja v koprski občini. Ljubljana, Inštitut za geografijo, 148 str.

Špes, M., 2000. Geografske značilnosti pokrajinsko ranljivih območij v Sloveniji. Geographica Slovenica 33/1, str. 9-46.

Špes, M., 2001. Ranljivost okolja na območju mestne občine Koper. Ljubljana, Inštitut za geografijo, 136 str.

Tretji pomol Luke Koper. 2004. Posebna izdaja, december. Koper, Luka Koper d.d., 8 str

\section{ODNOS PREBIVALCEV MESTNE OBČINE KOPER DO LUKE KOPER}

\section{Summary}

Luka Koper is indeniably a very successful Slovenian company with constant rising of gains and increasing of port and logistic services. On the regional level its importance is linked to direct employment, yet there are numerous companies that depend on Luka Koper. The main vision of Luka Koper is to become the leading logistic, distributional and transport sistem for Eeast and Central European countries.

Exceptional economic, transport and gravitational importance of the port is on the other hand confrontet with the impacts on the environment. Coastal ecosystem in the shallow bay of Koper is extremely fragile. In this fragile region the interest of port activities, tourism and the citizens wish for unpolluted environment meet.

With the help of our survey we have shown what the general attitude towards Luka Koper is like on the level of the whole community in Koper, as well as explained the reasons for this growing dissatisfaction among the people. We have also defined the resident groups that oppose the expansion of the port and presented the effects of the port which residents detect in different areas of their community.

$8 \%$ of the citizens declared explicitly declinatory towards Luka Koper, positively declared $84 \%$ of the citizens. Citizens mostly realize the economic importance of Luka Koper, that is why they are also more tolerant to its environmental impacts.

On the level of the whole community $20 \%$ of the questioned perceive observable impacts of port activities upon environment, only in Ankaran there is a half of questioned citizens who perceive negative impacts. This is easyly understandable, as when approaching the port level of perception of the impacts grows. Criticism agains port impacts also grows with higher education of citizens. The importance of Luka Koper is most highly estimated in 
working fields (industry, transport) which depend on port activities.

The main aim of the project was to analyse citizens' attitude towards the foreseen Pier III. $63 \%$ of citizens agree with the construction of the new pier, $20 \%$ oppose the extension of the port. In Ankaran (the nearest settlement to the port) there is one third of asked inhabitants that agree with the extension.

The attitude towards Luka Koper in Ankaran is in comparison to other parts of the community destinctly different. However there is not a prevailing opposition to the construction of Pier III.

On the whole the citizens of Koper community do not have a prevailing negative attitude towards the port. Huge economic importance of Luka Koper on the regional and also on the national level increases tolerance of its impacts upon the environment. 